\title{
The Transformation of Values in A Catfish Folklore
}

\author{
Uril Bahruddin \\ Fakultas Ilmu Tarbiyah dan Pendidikan, Universitas Islam Negeri Maulana Malik \\ Ibrahim Malang, Indonesia \\ email: urilbahruddin@uin-malang.ac.id \\ Qomi Akit Jauhari
}

Fakultas Ilmu Tarbiyah dan Pendidikan, Universitas Islam Negeri Maulana Malik Ibrahim Malang, Indonesia email: qomiakit01@uin-malang.ac.id

Nur Faizin

Fakultas Sastra Universitas Negeri Malang, Indonesia email: nur.faizin.fs@um.ac.id Muhammad Widus Sempo

Fakulti Pengajian Quran dan Sunnah, Universiti Sains Islam Malaysia email: widus81@usim.edu.my

\begin{abstract}
Industrial developments have brought many significant changes in various fields of life, especially agriculture and education. It seems that the transformation of the agricultural sector and fishpond farming in Medang Village, Glagah, Lamongan are affected by the catfish folklore that keep the people concerned for generations. This is a phenomenological research and the results are descriptive and qualitative. The data are described and interpreted hermeneutically. The results indicate that the catfish folklore contains a number of educational values that dynamically developed along with the people's beliefs about the
\end{abstract}

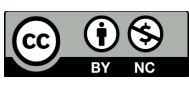

DOI: $10.19105 /$ karsa.v28i2.3520 
folklore as a myth. This transformation of educational values includes: the value of ubudiyyah, the value of the struggle in the life; and the moral value. This transformation occurs through the intervention of many parties, both internal and external ones, such as the local government, the elders, the community leaders as well as educators. Other factors are technological development and the development of the fishery industry. This research suggests the stakeholders of the village level, districts, and regencies to make the folklore as a medium in learning the educational values. The society, especially the fishpond farmer at Medang village are suggested to preserve the folklore without preventing it to be known. The scholars and the artists can also bring this folklore to life and present it in a more interesting format, both in a pure and classic appearance and in collaboration so that it can be presented as a myth that has a profound meaning.

[Perkembangan industri tampaknya membawa perubahan signifikan terhadap berbagai bidang kehidupan, khususnya pertanian dan pendidikan. Transformasi sektor pertanian rasanya tak dapat terhindar, termasuk pertanian tambak yang berada di Desa Medang Kec. Glagah Kab. Lamongan dengan folklor tentang ikan lele yang turun temurun menghantui mereka. Penelitian ini adalah penelitian fenomenologis dengan uraian hasilnya yang bersifat deskriptif kualitatif. Data-data dideskripsikan dan ditafsirkan secara hermeneutis. Hasil penelitian menunjukkan bahwa folklor ikan lele mengandung sejumlah nilai yang berkembang secara dinamis seiring kepercayaan masyarakat tentang cerita itu sebagai mitos. Transformasi nilai-nilai meliputi: nilai ubudiyyah, nilai perjuangan; dan nilai moral. Transformasi ini terjadi melalui campur tangan banyak pihak, baik internal maupun eksternal, seperti pemerintahan desa, orangtua, tokoh masyarakat, dan juga pendidik serta faktor lain seperti kemajuan teknologi, perkembangan industri perikanan. Penelitian ini merekomendasikan kepada steakholder level desa, kecamatan, dan kabupaten, bidang formal untuk menjadikan cerita folklor ini sebagai media pembelajaran nilai-nilai. Masyarakat, khususnya para petani tambak Desa Medang disarankan melestarikan cerita tersebut tanpa menghalangi untuk membudidayakannya. Budayawan dan seniman juga dapat menghidupkan cerita ini serta menampilkannya dalam format yang lebih menarik, baik dalam penampilan yang murni klasik maupun kolaborasi sehingga mampu menghadirkannya sebagai mitos yang bermakna mendalam.]

Keywords: folklore; catfish; moral values; transformation

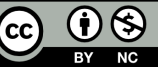

DOI: $10.19105 /$ karsa.v28i2.3520 


\section{Introduction}

The farmers in Lamongan have been interested in fishpond farming through fish farming, including catfish farming since this fish has been known as a commodity that is easy to be marketed. It can be processed as side dishes to be eaten daily and processed food like chips and others. Besides, the catfish farming does not need a wide pond, so it is easier to handle than other types of fish farming, such as milkfish and tilapia fish. Furthermore, Lamongan has a vast fish market, and there are many middlemen who come to the remote areas in the village to buy catfish with a good price.

One of the myths believed by the people in Lamongan tells that all descendants of Mbah Boyohpatih are banned to eat catfish. One who violates that prohibition is assumed to be aware of the risk of suffering from itch, peeling skin, or having white-strips that are similar to catfish skin. The habit of doing ziarah or visiting the graves of Mbah Boyopatih is closely related to the story that is shared from generation to generation telling about Sunan Giri's pupil who had passed away and was buried in Medang Village, Glagah district. ${ }^{1}$

Myth is a form of folklore that reflects the culture of a certain area where the story is spread and developed. ${ }^{2}$ The catfish myth was taken from a folklore that grows among the society in Lamongan and its surrounding areas. The folklore that has been told orally from one to another, from generation to generation, without any definite meaning or understanding, has become an appealing topic to be observed and investigated.

Folklore becomes a significant matter to be studied, particularly for educators who are going to teach about educational values and convey them to certain group of people. Folklore has been taken as an essential source for the educators who want to know their students better

\footnotetext{
${ }^{1}$ Nono, Naskah Riwayat Hari Jadi Lamongan (Lamongan: The Culture and Tourism Department, 1889), 9.

2 Dundes Alan, Folklore; The Analytical Essays of Alan Dundes (USA: USUPress, 2007), 55.
} 
as well as to be able to instill a good insight into the students' point of view about the world and life. ${ }^{3}$

The study on the folklore that develops among the society or becomes a part of the culture of the society needs identification and interpretation. The study about folklore does not only become the anthropologists' interest or the scholars who study literature, but it also becomes a crucial thing for educators in their work life. According to W. Bascom, folklore has at least four functions, namely: a collective projection system, a means of legality towards institution and culture, a media, and a controlling tool for the society norm. ${ }^{4}$

The development of industry that has reached out to the millennial generation seems to have brought a quite significant change in the farming world. The villages in Glagah district, Lamongan regency, have experienced the transformation in the agricultural sector and fishpond farming. Transformation is the postmodern paradigm that has been developed as a counter to modernism school. The postmodern paradigm is a paradigm about the aesthetics of literature, politics, and social philosophy that turned out to be a way for mapping out the institutional condition or the post condition of the modern thinkers. ${ }^{5}$ This postmodern paradigm occurred because of the transformations happened in various fields with the new model and form, including in the filed of literature and science.

The postmodern condition mentioned above needs a transformative renewal. To provide a comprehensive support to the society based on the needs and demands, a proper depiction of the condition is needed. Without a good understanding concerning the concept, one of the aims, which is to shape a nation that has a noble character, will be impossible to achieved.

The concept of educating eventually becomes a concept that needs to be developed to counterbalance the transformation. In this industrial era, phenomenal changes or developments that occurred

\footnotetext{
${ }^{3}$ Dundes Alan, Folklore, 55.

${ }^{4}$ WilliamBascom, Four Functions of Folklore (USA: Englewood Cliffts, 1965), 13-20.

5 Madan Sarup, Strukturalisme dan Postmodernisme; Sebuah Pengantar Kritis (Yogyakarta: Jendela, 2003), 15.
}

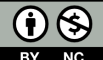

DOI: $10.19105 /$ karsa.v28i2.3520 
among the society are indispensable so that the study that has a transformative paradigm is also important to do to achieve the goals of mapping out the changes happening within then society in Lamongan. This mapping is used to build a concept that is relevant to the needs and demand that actually happen.

The Indonesian folklores generally contain syncretism of various values, including the syncretism of Islamic values and Javanese beliefs as what can be seen in the rituals of prayers and marriage ceremonies, grebeg keraton, and others. ${ }^{6}$ Moreover, the numerous forms of folklores, and the oral stories or storytelling is not an exception, may contain particular values. These values are transformative ones that have dynamic changes among the local society, including the people in Lamongan.

The story about catfish is a folklore that contains Islamic values for the people live in Medang village, Glagah district, in Lamongan regency. ${ }^{7}$ This folklore has become a myth believed by the society; thus it has a cultural influence on the society. In fact, many people still believe the story and obey the unwritten rules; however, some people do not believe it anymore and start to ignore it.

The existence of the folklore that becomes a myth can be marked by the usual activities conducted by the society that is the ritual to do ziarah, or visiting the grave of mbah Boyohpatih, on Friday pon (based on the Javanese calendar) by bringing some flowers or other things to be spread or put on the burial ground. This contains some undeniable values, such as the values of being obedient towards the parents and respecting the parents' utterances and advices. These values are inseparable from the folklore that encompasses some meanings and commands like the catfish and mbah Boyohpatih story.

This study, firstly, aims to find out the meaning of the cultural phenomenon related to the catfish myth occurred in the society. The interpretation of this folklore is truly needed since a folklore will be

\footnotetext{
${ }^{6}$ Bani Sudardi, "Ritual dan Nilai Islami dalam Folklor Jawa," Islamic Culture Journal, no. 13, (June 2000): 301.

${ }^{7}$ Muhibbatul Hasanah, "Mitos Ikan Lele: Studi Deskriptif Masyarakat Desa Medang, Kecamatan Glagah, Kabupaten Lamongan,” BioKultur, no. 2, (June 2013): 160-165.
}

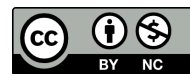


merely a made-up story if there is no interpretation. Through an interpretation, a phenomenon can show some meanings. Therefore, hermeneutic analysis is needed to perform in order to understand and interpret the folklore. ${ }^{8}$

Secondly, this study tries to see the transformation of finding out the meaning of the catfish myth believed by the people in Lamongan, especially those who live in Medang village in Glagah district. The society's life style that has changed from agricultural society to modern industrial society have brought a significant change that makes a study focusing in a transformative paradigm possible. Transformation is a change of form happening within the society. Transformation can be understood as a pattern that remains the same, but it has another form. ${ }^{9}$

Thirdly, this study attempts to find the relevance of the values, based on the analysis, to the real world. Hence, the formal practitioners can use it as a reference to shape the learners' characters by instilling a noble character into the learners' personality. It is somehow disappointing that the news about students who harassed their teachers and children who beat up or even killed their parents are still frequently heard and seen.

\section{Methods}

This study employs a phenomenological approach and it has descriptive and qualitative results. The data gained from the society are described and investigated to obtain the desired result. This study uses a qualitative approach, which can help to gain answers concerning any signs, facts and reality that the researchers meet as well as to provide a new understanding and meaning about the problem after analyzing the existing data. ${ }^{10}$ Qualitative study attempts to understand a phenomenon in a social context naturally by prioritizing a deep communication and

\footnotetext{
${ }^{8}$ Suwardi Endraswara,Metodologi Penelitian Folklor, Konsep Teori dan Aplikasi (Yogyakarta: Medpres, 2009), 151.

9 Heddy Sri Ahimsa Putra, Strukturalisme Levi Strauss: Mitos dan Karya Sastra (Yogyakarta: Kepel Press, 2006), 60-61.

${ }^{10}$ J.R. Raco, Metode Penelitian Kualitatif Jenis, Karakteristik, dan Keunggulannya (Jakarta:Raja Grafindo, 2010), 33.
}

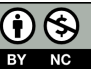

DOI: $10.19105 /$ karsa.v28i2.3520 
interaction process between the researcher and the observed phenomenon. $^{11}$

The data collection techniques chosen are observation, interview and documentation. The data analysis is conducted by using a descriptive-qualitative method comprising data reduction, data presentation, and data verification or concluding. In a qualitative study, the verification is performed by analyzing and finding out the meaning of the collected data. Furthermore, the researcher tries to find the pattern of the theme, explanation, configuration, and the relation of the similarities. Then, they are arranged for drawing conclusions.

\section{Results}

Building a good individual character, a state that has a noble character, and well-educated human being are the responsibilities of all parties; not only individuals but also the society, the state and the government. These have been regulated by the law. A good human being who has a noble character and is well-educated can be generally seen from the culture that develops among the society. The values that are considered as the forms of appreciation for certain quality based on particular systems of beliefs have grown within the culture. As the establishment of freedom to speech and freedom of expression, people always blame educators for any events violating norms and values in certain culture and belief. The increase of juvenile delinquency is always related with nation failure. Therefore, there is a demand for an institution to develop values in order to create generation which inherits noble values of the culture and belief.

Character building is not only to spread information, but it also becomes a demand by field experts. Character building should be taught with good values existing in the culture and belief of the society or nation. Therefore, the understanding of all responsible parties for the values of a nation or society is important. With these values, a society or nation can be considered as being right or wrong. Kamus Besar Bahasa Indonesia (KBBI) defines value as important and beneficial

11 Haris Herdiansyah, Metodologi Penelitian Kualitatif untuk Ilmu-Ilmu Sosial (Jakarta:Salemba Humanika, 2010), 9.

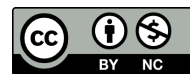

DOI: $10.19105 /$ karsa.v28i2.3520 
characteristics and things for humanity. It is also something completing humans according to their essence. ${ }^{12}$ Value encourages someone to do or leave something. Someone's wisdom and humanity will grow optimally whenever he or she already has the values. It goes the same with a society or even a nation.

\section{The Descendants of Boyohpatih}

Boyohpatih forbid his descendants to consume catfish. The society which was the heirs of Boyohpatih kept telling this forbidance to their next generation. Now these people have moved to many areas such as Lamongan, Gresik, Surabaya, and Tuban, and even outside Java island. ${ }^{13}$ Even though they have left Medang village and are far away from Boyohpatih, they still believe that they cannot eat, sell and deal with catfish.

Generally, the society who believes the story of Boyohpatih follows the patriarchal tradition. It is similar with Islamic teaching in which someone's lineage is from his father instead of his mother. Someone is considered as Boyohpatih's descendants if his father is one of Boyohpatih's descendants. However, the researcher found out someone considered to be Boyohpatih's descendant even though it is from the mother lineage. The data shows that patriarchal culture still dominates this society. However, it is erroded by local culture which considered a spouse as two individuals who have equal responsibility.

The researcher also found many data showing few husbands who are the descendants of Boyohpatih forbid their wives to eat catfish and vice versa. Besides the descendants of Boyohpatih, the new comers who have married and have children and settle in Medang village believe the

12 Compilation Team, The Great Indonesian Dictionary (Kamus Besar Bahasa Indonesia or KBBI), Ministry of Education and Culture, offline version 1.5. see the entry "nilai".

${ }^{13}$ When many pilgrims came to the grave of Boyopatih on Friday Pon, the researcher asked their origin and they said that they came from Gresik and they were the heirs of Boyohpatih. Some of them came from Cirebon, Jakarta, Bandung, Tangerang, etc and they were also the heirs of Boyohpatih.

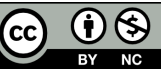

DOI: $10.19105 /$ karsa.v28i2.3520 
story. The researcher interviewed one of the families and they respect the tradition and obey the forbiddance not eating catfish.

The lineage of Boyohpatih is not written as other important lineage. It is told using word of mouth only. So, it is possible that a mistake occurs in the lineage.

\section{Pilgrimage of Boyohpatih Grave}

The society in Medang believes that Boyohpatih is one of friends of Allah (waliyyullah). He got his sainthood because of his devotion to his teacher, Sunan Giri. Beside that, many of pilgrims come to the grave of Boyohpatih to get recovery, blessing, and longevity. They come to the grave of Boyohpatih every Friday Pon or the certain momentum. The researcher meets up with a pilgrim who regularly goes to this grave before he works on his rice field or fishpond.

Beside Friday Pon activity, there are activities like Haul program that filled by tahlilan, manaqiban, and religious lectures. It is held annually and attended by the villagers around the grave. Before the activities begin, the Medang village government holds a discussion and creates the publication in order to inform the society about this program. It is usually hold after harvest time.

When the pilgrims come to this grave, they usually buy the flower to strewing flowers on Boyohpatih tomb or in its side. They can buy the flowers in the parking area. It is worth 5000 IDR or 10000 IDR for a pack. Then, the flower packages are opened and put on Boyohpatih's tomb accompanied by small change of 2000 IDR, 5000 IDR, or 10000 IDR. They call it as slawat ${ }^{14}$ Boyohpatih. The researcher asked to the pilgrim about what his purpose puts the small change on it and for whom that small change is. Then he answered: "kangge slawat, mugi-mugi slamet" (it is for slawat (prayer) in order to get safety)

The researcher observed that small changes on the flowers were put in charity box around the grave then the small changes were collected by grave duties who manage it. Based on the information, its

\footnotetext{
${ }^{14}$ According to the researcher, slawat is derived from the word shalawat, which is generally a prayer for the Prophet Muhammad PBUH. The word shalawat is derived from the same base word "shalat" that means "prayer" in Arabic.
}

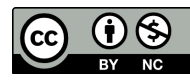

DOI: $10.19105 /$ karsa.v28i2.3520 
amount can reach up to two million in a month. Thus, the management of Boyohputih grave becomes the responsibility of village government in Medang. Then it sold on the society with worth ten million in a year as the village income.

\section{Catfish as Livestock Fish}

Changes in the organizational structure related to the economy are also undergoing transformation in this fast developing era. The changes are directly related to production, marketing or distribution. The strong changes in the current industrial era have increasingly encouraged the people of Medang village to maximize the potential they find within them in sectors of agriculture or trade as well as encouraged some of the residents of Medang village who no longer live there to be more creative.

In providing productions, the people of Medang village and the descendants of Boyoh patih have been undergoing a transformation of values. The first transformation phenomenon that is interesting to observe in this study is the transformation of the value of the catfish. In the past, catfish were believed to be the savior of their ancestors, but nowadays catfish are no more than ordinary farmed fish that can be bred next to their houses. It is even considered as a savior fish in economic when some of their offspring who are "forced" to live as a catfish seller with a fried catfish stalls. For various reasons, some people have made catfish only as livestock fish and consumption fish which produce money to meet their needs.

The techniques used by the Medang community and Boyohpatih descendants in catfish farming have also changed. In the Medang community and its surroundings, catfish farming is no longer using jublangan media or a kind of small pond, but a large area, then it is done by making bulkheads from fishing net material to separate the catfish seeds and other parts processed for the rearing. This is necessary because if it is mixed, the small catfish will be eaten by the big fish when feeling hungry.

Some people of Medang village also work as fish sellers in the traditional market in Lamongan district and they are used to selling

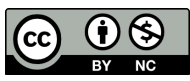

DOI: 10.19105/karsa.v28i2.3520 
catfish. For example, Mrs. Siti Rohmah and her spouse Mr. Kholil are catfish sellers or collectors who come to remote villages around Medang who are ready to lend money to buy fish seeds, to supply catfish food, and finally to harvest and collect the catfish from these farmers to be distributed to the big fish market in Lamongan district. Mrs. Siti said: "lha yok opo maneh pak, ne gak ono seng gelem dadi juragan yo sakno petani-petani lele iku"15 (What is happening if there is no middleman who will buy the catfish, sir? The farmers will be in loss).

\section{Management Transformation}

The researchers also found the changes related to ownership and investment rights in the income and investment management. The people of Medang village, especially the village government, have transferred their management to the party that carries out the management contract, which is usually chosen according to a joint decision at a village meeting. The management of Boyohpatih's graves includes managing the parking lot and parking arrangements for the vehicles of the pilgrims as well as cleaning and collecting slawat left by pilgrims around the Boyohpatih grave.

Management by the village government of Medang is a development that is influenced by capitalistic management where there are owners or investors and workers. The management in the era of the industrial revolution is increasingly developing, touching at all levels of life, even though it cannot be avoided that it has entered remote villages such as Medang village. According to the researcher, this capitalistic value encourages the village community to hand over the management of the tomb to certain parties with a contract system. The government officials are actually very capable of managing the Boyohpatih grave with the help of residents who are paid properly, instead of handing it over in full to a number of residents. If the management handled by the Medang village government, the village funds do not only rely on the central government but also monthly income from the grave.

The researchers see the management values have transformed that were previously not found at all but are now a phenomenon that is

${ }^{15}$ Interview with Siti Rohmah on July 11, 2019.

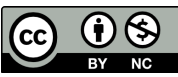

DOI: $10.19105 /$ karsa.v28i2.3520 
clearly visible and can even be accepted by the people of Medang village in general. According to Mr. Kasmiran, the management of the graves that was handed over to a number of residents benefited only some of the residents, especially those who dared to "buy" by contracting them annually. He said: "niku tiyang-tiyang ingkang ngurusi makam niku kesenengan, kantuk e tiap jumat pon ngeteniki saget jutaan, nanging tiyang-tiyang niku namun tumbas regi sedosoan juta setunggal tahun" 16 (the people who take care of the grave are really lucky, because every Friday pon they can get millions of rupiah, but they only buy ten millions in a year).

The idea of managing the grave that was contracted out by the Medang village government to a certain party was initially triggered by the distrust of some residents with reports of the slawat results that are collected every Friday, especially Friday pon, and the absence of proper care of Boyohpatih's grave by the village government. Therefore, the management authority was given to certain parties only. According to Mr. Sutahar, who serves as the Head of Public Relations in the village of Medang, the village government actually prefers this model of management, reducing its duties more. He said: "kulo tambah seneng mboten nderek ngurusi, mboten kakean omongan ngetan ngeten" ${ }^{17}(\mathrm{We}$ are happier not to take care of (Boyohpatih's grave) because there are not many rumors).

\section{Discipline Transformation}

The transformation of the discipline value in the catfish folklore, which was previously perceived as the return of borrowed goods that should have been returned on the due date, but in today's development, the value of this discipline is evident in the object of our research around Boyohpatih's grave. The discipline of the community which is automatically applied on every Friday Pon to pray and hold activities is a value that continues to be developed. If someone is absent, then one of the family must represent him.

${ }^{16}$ Interview with Mr. Kasmiran on Friday, July 19, 2019.

${ }^{17}$ Interview with Mr. Kasmiran on Thursday, July 18, 2019.

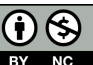

DOI: $10.19105 /$ karsa.v28i2.3520 
In the folklore story of catfish, it is also mentioned that one of the disciplinary values has recently been distorted in the myth that has manifested in the beliefs of the offspring and will come down from Boyohpatih. It is as if every parent feels obliged to tell that he is a descendant of Boyohpatih so that his children are not allowed to eat catfish. It proves the love of the mother and father to protect them from skin disease or other threatening harm.

Discipline of clothing is also evident. In general, the people of Medang village have started to follow a fairly modern dress model. Boyohpatih grave management uniform is also an observation that researchers pay attention to. All officers on duty at that time wear a green vest uniform with the word "officer" on it. According to Mr. Mustahar, in recent years they have begun to be disciplined in this task.

According to researchers, the changes in management models, the structure and the performance of village government as well as decision making have a lot of influence on the value of the normative system in the community, including emphasizing the value of discipline applied in the management of Boyohpatih's graves as one part of Medang village assets that provides income to the village government and more professional management.

\section{Discussion}

\section{Various Values}

Based on the source that a value is emerged and developed, there are two types of values: Divine and human value. ${ }^{18}$ First, divine value is originated from God. Believing in one God, this nation accepts that noble values will lead human to be kind, fair, and generous. The belief to the divine value is sacred and has agreement aspect. With this value, human should be able to have a good relationship with God (vertical relationship) and other people (horizontal relationship). It includes faith and resignation leading to peacefulness, and it encourages human to behave properly in economical, political, social practice and in the society Second, Human value is originated and developed based on

\footnotetext{
${ }^{18}$ Muhaimin dan Abdul Mujib, Pemikiran Islam, Kajian Filosofis dan Kerangka dasar Operasionalnya (Bandung: Triganda, 1993), 110.
}

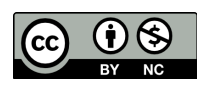


agreement among humans. A civilized community has values to maintain and preserve. These values always develop dynamically and in the same time being relative in accordance with the society and its belief and culture.

Abraham Maslow as cited by Chabib Thoha mentions some types of value from the aspect of human needs: physiological, safety, love, self-esteem, self-actualization. Seen from the aspect whether human can develop the value or not, there are two values: static and dynamic value. Static value includes cognition, emotion, and psychomotor. Meanwhile, dynamic value is a motivation to achieve something. From the aspect of cultural process developed in a society, values are classified as: knowledge, economical, art, political, religious and cooperation value. ${ }^{19}$

Value in Islamic perspective is a soul which becomes foundation or supports the speed and movement. It includes: 'ubudiyyah, morality, and discipline value. ${ }^{20}$ 'Ubudiyyah or divine value is an awareness and potency of humans as God creation who are obliged to worship and obey God by following His rules, by practicing His order and avoid His prohibition. It leads to gratefulness, patience, optimism, and consistency in living properly based on God's fate.

Morality value is a core of Prophet Muhammad pbuh teaching, since he was sent to perfect noble character. Human with good character and moral becomes an objective in a process. Islam has great concern about morality value and already gives the key, that humans should manage their hearts in order to behave and act properly. God asks humans to control their hearts (a lump of blood in their bodies). Prophet Muhammad pbuh said that: Remember that there is a piece of flesh in the body if it becomes good (reformed) the whole body becomes good but if it gets spoilt the whole body gets spoilt and that is the heart.

Disciplinary value emphasizes that humans should behave and act in order, in control and with plan. People should have a determined target in living their life and proper and measured process toward the objective. Muslim are expected to be smart, have a scientific ability,

${ }^{19}$ Chabib Thoha, Kapita Selekta Islam (Yogyakarta: Pustaka Pelajar, 1996), 68.

${ }^{20}$ Solikin, Transformasi, 6.

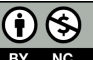

DOI: 10.19105/karsa.v28i2.3520 
have a good work ethos in order to be positive human. Their existences are beneficial for their communities and people around them, rather than being destructive human who causes problem and disaster.

\section{Value Transformation}

The term of transformation is often used to describe social changes and it generally shows a critical opinion toward old ideas. Social transformation approach considers that western model does not have to be adopted by other countries. On the other hand, this change power nowadays also creates crises for old industrial countries. The study on social transformation is expected to be research field leading to positive steps for social and political acts to protect local and national communities from the negative consequences of global changes.

Generally, social transformation concept in social sciences refers to social systemic characteristic changes. The transformation refers to changes of parameter existing in social system, including technological, economical, political and cultural restructurization. Historically, it is accepted as global information tecnological change. Economical transformation is changes in property rights, investment, production, distribution and supplies. Political transformation means changes of political power use in taking different forms. Transformation involves changes in structure and performance of governmental institutions and other decision and control makers. Eventually, social value normative system also changes acceleratively.

The transformation of social values influences all levels of society, both in developed and developing countries, creating new form of social differentiation in any level, polarization and gap which become problems in the future. The study on social value transformation refers to various ways global power impacts on local community and national society with various historical experiences, economical and social pattern, and political and cultural institutions. Hence, every social value transformation analysis needs social-macro, tradition, experience, and local identity analysis.

The previous values existing in a society or nation can be eroded by these changes and modernization. The country side communities

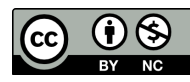

DOI: $10.19105 /$ karsa.v28i2.3520 
which used to consider folklore as media now is influenced by the modernization and global discourse. The economical demand needs a quick response and it also becomes difficult to fulfill.

\section{Islamic Value in Catfish Folklore}

a) Ubudiyyah Value

In this folklore of catfish, the value of a student's obedience to his teacher is clearly visible. The obedience of a student to take the heirloom of his teacher is carried out so responsibly that the Boyohpatih also mobilizes all his abilities. This is an example that has recently begun to fade and disappear, especially in the formal, which is interpreted as the transfer of knowledge, not the formation of personality and character. In the same story, openness is needed even though it is done in order to take right that is clearly his own right. It is also important to pay attention to how to obtain proprietary, especially when what is to be achieved is goodness. Goodness that is achieved in an unkind manner will eventually lead to undesirable situations. The way to get the heirloom carried out by Boyohpatih certainly triggered the chase he experienced until he was finally cornered and had to be saved by the catfish.

Religious values is the spirit that becomes the driving force for the continued pace of religion. These values can be found in the catfish folklore in Medang. Among the religious values that are clearly visible is the ubudiyyah value, which is always the motive for the loyalty and obedience of the descendants to their parents. In the present, where many people who no longer care about obedience to their parents and children feel that they have lived in a time that is far different from their parents, the loyalty and obedience of children to their parents.

The value of ubudiyyah is also manifested in giving alms by giving food (slametan). Giving alms and slametan are values ordered by religion, especially by Islam. There are so many rich people who always accumulate their wealth without wanting to look at those around them who are in need. By giving slametan, pilgrims maintain the values of these Islamic teachings. Gratitude is a value that also very clearly arises from the habit of giving the slametan.

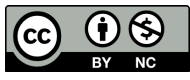

DOI: 10.19105/karsa.v28i2.3520 
The researcher also met up with the visitors who made a pilgrimage to Boyohpatih grave and thought that the pilgrimage to the grave was a worship value. It was slightly different from the general pilgrims who came for tabarukan (seeking blessings) from the grave. The ubudiyah value that exists in him is that the death of a person who is full of struggle in his life will definitely be remembered by the society and get prayers from them. A situation that is very different from the death of ordinary people or even people who have committed crimes and badness in their lives, their death is considered as a gift and mercy to the people.

\section{b) Struggle Value}

The struggle is generally known as terminology of jihad (fighting), although jihad itself is not only meant as struggle but also means seriousness in carrying out the commands of Allah SWT (QS. alAnkabut: 69). It is with this struggle that guidance from Allah can be obtained. Some of the people of Medang and its surroundings consider that Boyohpatih's seriousness in carrying out his teacher's order is one of the causes of the appearance of Boyohpatih karamah who was saved by a catfish and then his words became a curse to those who violate his words.

The value of this struggle is what encourages society to continue to maintain and preserve the habit of the pilgrimage to the Boyohpatih grave which was carried out by their ancestors until it has been passed down from generation to generation. In the tradition that has developed in the Medang society, a religious figure who is no longer able to carry out his duties or who has "retired" will still be respected as someone who has fought in their midst. For example, Mbah Tolib, who is now the caretaker of Boyohpatih grave, was a religious figure who served as a moden who took care of the dead, prayed for him after death, until the completion of prayer events that were usually done there. Mbah Tolib struggle continues to be rewarded by establishing him as the caretaker of the grave who more or less also gets life support from his job. In the interview, Mbah Tolib's wife said: "Mbah Tolib used to be a moden, taking care of the dead from bathed, covered, prayed, buried them until

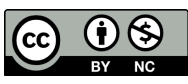

DOI: $10.19105 /$ karsa.v28i2.3520 
prayed for them for 7 days to one hundred days. But now Mbah Tolib is old, so the society trusts him to protect this grave." 21

The value of this struggle is also the reason for society to continue to give place to people who are considered to have services to society. The choice of moden substitute is also based on one's struggles in previous times. They think that good people and those who always appear in the front, not necessarily worthy of respect if they do not have a track record in the struggle in that village.

c) Moral Value

Moral value is related to ethic or moral. It guards person to be well-behave and full of self-decoration in his daily life. Praiseworthy morality is an important thing that must be developed in, because people who do not have it will easily take action that harms other parties in society. In general, it has been agreed that one of the important tasks in being able to embed noble and cultured values in the whole society. Being a human being with character is no less important than being an intellectual human being. Boyohpati's action, which prohibits his descendants from eating catfish, is an act that reflects noble morals, namely to return the favor even to a group of fish. According to many societies, the reason why Boyohpati issued this prohibition was because he had been saved by the catfish, so that in return for the catfish forbade himself and all his descendants to eat it. ${ }^{22}$

Another moral message is reflected in the value of parental obedience. Respecting the words of parents is the reason for a number of society who actually does not really believes in the influence of catfish in their lives, both health and others. However, based on the reason of respecting the words and prohibitions of their parents, they are reluctant to consume catfish. If in this era, there are many people complain about children's moral to their parents, then in Medang the children are relatively more obedient to their parents, at least in terms of prohibition of consuming or anything related to catfish.

\footnotetext{
${ }^{21}$ Interview with Ms. Qomariyah at the place of the graveyard's caretaker on July 18, 2019.

${ }^{22}$ Interview with Mr. Kurdani on July 17, 2019.
}

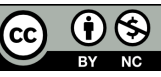

DOI: $10.19105 /$ karsa.v28i2.3520 
Boyohpatih also provide moral lesson about the ethics of a person visiting other people's homes. In the folklore, Boyohpatih would not have been pursued if he had not taken the heirloom by disguising himself and changing his form. Pak Mustahar said: "jane Mbah Boyohpati sabar nunggu sampek Mbok Rondo nguwehno yo malah apik, soale dia kan medayo." (If only Boyohpatih patiently waited until Mbok Rondo agreed to give the heirloom which would be even better, because he was currently visiting).

\section{Transformation of Value}

Scholars note that there have not been as many social changes as occurred in human history during this century. The terminology of transformation in the social field is widely used in order to provide an overview of changes in society. This transformation usually appears in the form of criticism in responding to old ideas. In transformational research in the social field, the strength of change can influence critical attitudes towards the models of order that have developed in society for a long time, even in the Western world, because changes in transformation studies refer to themselves in order to save and protect positive things as well as develop rational political sense and maintain the existence of the society at the local and national levels in order to avoid the bad consequences of global changes. The efforts made in order to incorporate these values into the soul and personality of the society is known as the internalization of values. Meanwhile, in relation to the effort to embed these values so that they are attached to themselves is the transformation of these values ${ }^{23}$.

The understanding of societal transformation refers to characteristic changes that are actually systemic in the society that is studied in this research. These changes include benchmarks changes used in the system of society, for example the technological structure, economic fields, as well as politics and culture. In particular, the influence of production infrastructure in society is capable of bringing about relatively new technological changes. In this study, researchers

${ }^{23}$ Fuad Ihsan, Dasar-Dasar Analisis Folklor (Yogyakarta: Pustaka Pelajar, 2011), 155.

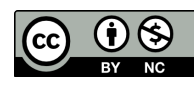


also found other factors such as technological advances, the development of the fishing industry and the narrowing of the land to make small ponds around the houses, public awareness of economic management also drove the value transformation of the catfish story, as well as the value of discipline carried out by the village government and the community in general.

\section{Ubudiyah and Moral Values}

Seen from a transformative point of view, these changes related to global information technology have led to changes in both ubudiyah or pure ritual values and moral values. Researchers saw that many pilgrims have visited Boyohpatih's grave, many of whom read holy Qur'an (including verses in surah Yasin) through an application on a smartphone. We also saw a shift in ethical values in pilgrimage which had lost the sacred side where pilgrims had started to use their cellphone cameras to take selfies in front of the grave, even in front of the gravestone, which according to the customs of the local people it was inappropriate. Based on the fact, the researchers find a contradiction, because on the one hand the village community has advanced in the use of technological developments, but on the other hand they still make this folklore a myth they believe in.

Ziarah in Islamic teachings, is a medium to remember death so that pilgrims get a reminder for themselves to always walk the path of Allah as in the words of the prophet Rasulullah (kafa bil mauti waidhan: death is enough to be a reminder) has now turned into either a redeemer, needs fullfilment or the wish maker of the pilgrims. Most of the pilgrims who made the pilgrimage that the researchers interviewed had an urge, nadzar that they wanted to be able to achieve or get rid of the illness. The recitation of Al Qur'an (and the surah Yasin), which should also be used to obtain guidance as well as to give blessings to the person who is buried, has now turned into a meaningless ritual, as a mere pilgrimage routine. The small book collections of Yasin and Tahlil in the Boyohpatih grave were scattered and not touched by pilgrims.

\section{(C) $)(1) \Theta$}

DOI: 10.19105/karsa.v28i2.3520 


\section{Conclusion}

The folklore about catfish in Medang village contain dynamic values and develop along with the times. There is one thing that has not yet undergone significant changes, which is related to the beliefs of some Medang villagers in the story as a myth that has an impact on their real life. In particular, this catfish story also contains values that are always alive. Ubudiyah values implied as the background of the catfish story carries the message of a religious life for the people of Medang village and the descendants of Boyohpatih who continue to tell it to their descendants to this day. The ubudiyyah values then encounter a transformation in the case of a Boyohpatih grave pilgrimage which is carried out on certain days, especially every Friday Pon and death anniversary. Pilgrimage to the grave is a reminder of death as well as to commemorate the history of the kindness of their figures and ancestors. The value of struggle was played by Boyohpatih for the sake of fulfilling the duties of his teacher (Sunan Giri) until he exerts all his abilities so that the task can be carried out according to the mandate given.

Medang villagers can also transform this value by always respecting the struggles of their predecessors. Moral values also live in the folklore about the catfish. Boyohpatih orders to descendants to do good to saviors is a high moral value, even though it is only fish. This moral value is then transformed by the people of Medang village in the children's obedience to their parents. Transformations in the Medang village community occurred because of the interference of many parties such as the village government, parents, community leaders and also educators. Informally, the story is kept alive to teach these values to the next generation. Even though the transformation is carried out informally in a school subject or in a classroom, the story is so inherent in the students. The other factors such as technological advances, the development of the fishing industry and the narrowing of the land to make small ponds around the houses, public awareness of economic management also drove the value transformation of the catfish story, as well as the value of discipline carried out by the village government and the community in general.

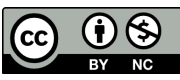

DOI: $10.19105 /$ karsa.v28i2.3520 


\section{Bibliography}

Alan, Dundes. Folklore: The Analytical Essays of Alan Dundes. USA: USU Press, 2007.

Bascom, William. Four Functions of Folklore. USA: Englewood Cliffts, 1965.

Endraswara, Suwardi. Metodologi Penelitian Folklor, Konsep Teori dan Aplikasi. Yogyakarta: Medpres, 2009.

Hasanah, Muhibbatul. "Mitos Ikan Lele: Studi Deskriptif Masyarakat Desa Medang, Kecamatan Glagah, Kabupaten Lamongan." BioKultur 2, no. 2 (2013): 157-166. http://journal.unair.ac.id/ download-fullpapers-004\%20jurnal\%20Muhibattul\%20H--mitos\%20lele.pdf

Putra, Heddy Sri Ahimsa. Strukturalisme Levi Strauss: Mitos dan Karya Sastra. Yogyakarta: Kepel Press, 2006.

Herdiansyah, Haris. Metodologi Penelitian Kualitatif untuk Ilmu-Ilmu Sosial. Jakarta: Salemba Humanika, 2010.

Ihsan, Fuad. Dasar-Dasar Analisis Folklor. Yogyakarta: Pustaka Pelajar, 2011.

Muhaimin, and Abdul Mujib. Pemikiran Islam, Kajian Filosofis dan Kerangka Dasar Operasionalnya. Bandung: Triganda, 1993.

Nono. Naskah Riwayat Hari Jadi Lamongan. Lamongan: Dinas Kebudayaan dan Pariwisata, 1889.

Raco, J.R. Metode Penelitian Kualitatif Jenis, Karakteristik, dan Keunggulannya. Jakarta: Raja Grafindo, 2010.

Sarup, Madan. Strukturalisme dan Postmodernisme; Sebuah Pengantar Kritis. Yogyakarta: Jendela, 2003.

Solikin. Transformasi Nilai dalam Islam. Surabaya: Kopertais IV, 2018.

Sudardi, Bani. "Ritual Dan Nilai Islami dalam Folklor Jawa. Bani Sudardi." IBDA': Jurnal Kajian Islam dan Budaya 13, no.2 (2015): 303-313. http://ejournal.iain purwokerto.ac.id/index.php/ ibda/article/view/665

Thoha, Chabib. Kapita Selekta Islam. Yogyakarta: Pustaka Pelajar, 1996.

\section{(c) (1) $\circledast$}

DOI: $10.19105 /$ karsa.v28i2.3520 
Tim Penyusun. Kamus Besar Bahasa Indonesia (KBBI). Jakarta: Kementerian dan Kebudayaan, 2001. 